\title{
Sacral Stress Fracture in Pregnancy: Case Report and Review of Literature
}

\author{
Gebelikte Sakral Stres Kırığı: Olgu Sunumu ve Literatürün Gözden Geçirilmesi
}

\author{
(D) Hamza Sucuoğlu****, (D) Adem Aktürk*** \\ *istanbul Gelişim University, School of Health Sciences, istanbul, Turkey \\ **Private Nisa Hospital, Clinic of Physical Medicine and Rehabilitation, Istanbul, Turkey \\ ***Private Nisa Hospital, Clinic of Radiology, Istanbul, Turkey
}

\section{Abstract}

Sacral stress fractures (SSF) are one of the rare causes of lumbar and hip pain during pregnancy. The purpose of this report is to present a case of SSF diagnosed in the second trimester of pregnancy along with its diagnosis and treatment as wells as the type of birth. A 27-yearold primigravid patient presented with lumbar and hip pain at 25 weeks of gestation. Magnetic resonance imaging revealed SSF. The patient was followed up with conservative treatment. She gave birth by caesarean section at 38 weeks of gestation. Bone mineral density analysis revealed pregnancy-related osteoporosis in the postpartum period. Two months later, the patient's symptoms were completely resolved. SSF should be considered in the differential diagnosis of lumbar and hip pain during pregnancy, and it should be kept in mind that these fractures may also occur in the prepartum period. Pregnancy-related osteoporosis is a risk factor for SSF. Caesarean section can be recommended as the type of birth in the women with SSF while considering the possible displacement risk for the fracture.

Keywords: Sacral stress fracture, pregnancy-related osteoporosis, lumbar, hip, pain

\section{Öz}

Sakral stres kırıkları (SSF), hamilelikte bel ve kalça ağrısının nadir sebeplerinden biridir. Bu raporun amacı, gebeliğin ikinci trimesterinde tanı konan bir SSF olgusuna tanı, tedavi ve doğum şekli sunmaktır. Yirmi yedi yaşında primigravid hasta, 25 haftalık gebelikte bel ve kalça ağrısı şikayeti ile başvurdu. SSF, manyetik rezonans görüntüleme kullanılarak tanı konuldu. Hasta konservatif tedavi ile takip edildi. Otuz sekizinci haftada sezaryen ile doğum yaptııılı. Kemik mineral yoğunluğu analizi doğum sonrası dönemde gebeliğe bağı osteoporozu ortaya çıkardı. iki ay sonra, hastanın semptomları tamamen düzeldi. Gebelikte bel ve kalça ağrısının ayıııcı tanısında SSF düşünülmeli ve bu kırıkların da doğum öncesi dönemde ortaya çıkabileceği akılda tutulmalıdır. Gebelikle ilişkili osteoporoz, SSF için bir risk faktörüdür. Sezaryen, bu kadınlarda, kırıma için olası yer değiştirme riskini göz önüne alarak, doğum tipi olarak önerilebilir.

Anahtar kelimeler: Sakral stres kırı̆̆ı, gebelikle ilişkili osteoporoz, bel, kalça, ağıı

\section{Introduction}

There are two types of stress fractures, which are insufficiency and fatigue fractures. Insufficiency fractures occur when normal stress is applied to the weakened bone, whereas fatigue fractures occur when excessive stress is applied to normal bone (1-5). These fractures, more common in the elderly, patients with weakened bones (neoplasic, metabolic, etc), and athletes (runners), are increasingly reported in recent years during the peripartum period $(6,7)$. Peripartum sacral stress fractures (SSF) are reported in literature as fatigue and insufficiency fractures (1-5). Pregnancy-related SSF is frequently reported during the postpartum period; however, to the best of our knowledge, only three cases are reported during the prepartum period $(1,4,8)$. SSF diagnosis can be delayed due to its rarity and unknown etiology and is included in the differential diagnosis of lumbar and hip pain in pregnant women. It is diagnosed via a vertical fracture line in the sacrum and edema in the surrounding bone as revealed by magnetic resonance imaging (MRI) $(4,9)$. Difficulties may be experienced in prepartum SSF treatment due to pregnancy; the question of which type of birth should be performed in these patients remains controversial $(1,4)$. Herein, we present a case of prepartum SSF and discuss these patients with their treatment and type of birth.

Address for Correspondence/Yazışma Adresi: Hamza Sucuoğlu MD, İstanbul Gelişim University, School of Health Sciences; Private Nisa Hospital, Clinic of Physical Medicine and Rehabilitation, İstanbul, Turkey

Phone: +90 5056297688 E-mail: hamzasucuoglu@gmail.com ORCID ID: orcid.org/0000-0002-8539-1834 Received/Geliş Tarihi: 09.11.2019 Accepted/Kabul Tarihi: 12.02.2020

${ }^{\circ}$ Copyright 2020 by the Turkish Osteoporosis Society / Turkish Journal of Osteoporosis published by Galenos Publishing House 


\section{Case Report}

A 27-year-old primigravid patient presented to our clinic with complaints of lumbar pain, left hip pain and antalgic gait at 25 weeks of gestation. The patient stated that she felt mild hip pain for 2 days that spontaneously occurred and then had difficulty walking due to a sudden aggravating pain. There was no known comorbidity, who did not smoke, drink alcohol, or use drugs. Obstetrics examination and abdominal ultrasonography revealed no pregnancy-related problems. In physical examination, the patient with antalgic gait had marked tenderness in the palpation of the left sacrum region. Left hip movements were free in all directions but painful. The Gaenslen and Patrick tests were positive. Neurological examination were normal. Radiography could not be performed due to pregnancy, and pelvic MRI showed nondisplaced oblique and vertically fractured line in the left sacral region and edema in the surrounding bone (Figure 1a). Laboratory tests performed to investigate the etiology of the fracture revealed that parathormone, $25-\mathrm{OH}$ vitamin $\mathrm{D}$, calcium, phosphorus, and alkaline phosphatase levels were normal. The patient was conservatively treated with SSF diagnosis. Rest, sacroiliac pregnancy belt, and paracetamol [1-2 gram (g) daily] as analgesic were recommended. Additionally, oral vitamin D (880 international units daily) and calcium (1 g daily) supplementation was given. Patient follow-up at 38 weeks of gestation showed that the pain was almost completed relieved and that the patient was able to walk with ease. Considering the risks that normal vaginal delivery (NVD) may enlarge and displace the sacral fracture, the fetus was delivered by cesarean section. The patient delivered a healthy girl weighing 3.340 $\mathrm{g}$, and pelvic MRI taken on the $10^{\text {th }}$ postpartum day revealed that the fracture line in the left sacral area had become less clear and bone marrow edema had diminished (Figure 1b).

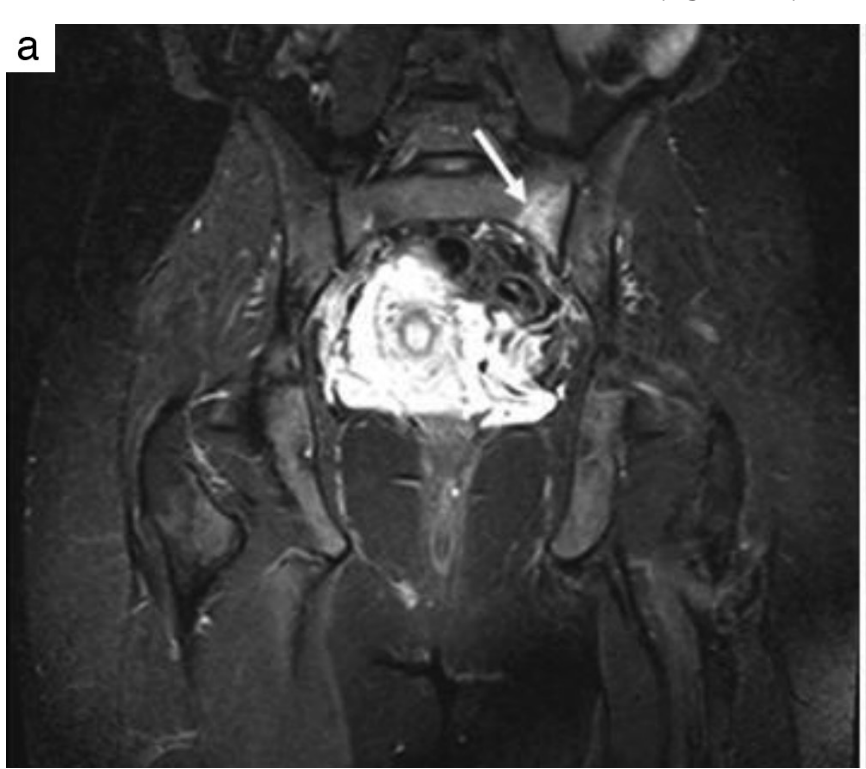

Bone mineral density (BMD) of the patient was measured using dual-energy X-ray absorptiometry at postpartum month 1, and osteoporosis diagnosed was made (Table 1) (10). The patient had no other risk factors for osteoporosis other than pregnancy and was diagnosed with pregnancy-related osteoporosis ( $\mathrm{PrO}$ ). Her treatment was continued with vitamin D and calcium replacement. The patient continued to breastfeed. Postpartum month 2 follow-up revealed that the patient's complaints and examination findings had completely resolved. Written informed consent was obtained from the patient for this article.

\section{Discussion}

\section{Definition and Epidemiology}

First reported by Lourie in 1982, SSF are insufficiency and fatigue fractures of unknown etiology (6). Although the exact incidence of these fractures is unknown because they can be overlooked during diagnosis, their incidence is reported to be between $1 \%$ and $1.8 \%$ in the patient population at risk $(11,12)$. Lumbar and hip pain is common during the peripartum period; however, SSF

\begin{tabular}{|c|c|c|c|}
\hline Skeletal region & $\begin{array}{l}\text { BMDa } \\
\left(\mathrm{g} / \mathrm{cm}^{2}\right)\end{array}$ & $\begin{array}{l}\text { *Z-score } \\
\left(\mathrm{SD}^{\mathrm{b}}\right)\end{array}$ & $\begin{array}{l}\text { T-score } \\
\left(S^{b}\right)\end{array}$ \\
\hline Spine (L1-4) & 0.914 & -1.4 & -1.8 \\
\hline Femur total & 0.695 & -2.2 & -2.5 \\
\hline Femur neck & 0.756 & -1.5 & -1.7 \\
\hline
\end{tabular}

aBMD: Bone mineral density, ${ }^{b} S D$ : Standard deviation, *Z-score: Recommended in premenopausal women (The International Society for Clinical Densitometry recommends the use of BMD Z-scores in premenopausal women, where a Z-score of lower than -2.0 should be interpreted as "below the expected range forage") (10)



Figure 1. (a) In the prepartum period, magnetic resonance imaging (MRI) of the pelvis demonstrated bone fracture in the left sacral ala. On T2 coronal sequence the fracture line was seen as an oblique and vertically, high signal line surrounded by an area of edema. (b) In the postpartum period, coronal short-tau inversion-recovery sequences of sacroiliac MRl; it was seen that the fracture line in the left sacral area had become less clear and bone marrow edema had diminished 
diagnosis is overlooked during pregnancy due to the relief of pain after birth and imaging methods being rarely used during prepartum period; therefore, the actual incidence is thought to be higher than what is reported $(6,13)$. Although cases during pregnancy are reported especially during postpartum period, our case of sacral insufficiency fracture is one of the few cases reported during prepartum period $(1,4,8)$.

\section{Clinical Features}

Patients are usually admitted with spontaneous lumbar and hip pain. Gaenslen and Patrick tests can be positive during examination. Pain and tenderness can be localized by palpation, especially on the sacrum. Antalgic gait and functional limitation may occur. However, none of the examination findings are specific $(1,4,14)$.

\section{Risk Factors}

Patients with conditions that impair bone quality, like osteoporosis, neoplasm (multiple myeloma), bone diseases (osteomalacia, Paget's disease), and hyperparathyroidism, in addition to elderly people and athletes are at risk for stress fractures $(6,7,15)$.

SSF risk factors during pregnancy include forced or rapid vaginal delivery, excess weight gain during pregnancy, hyperlordosis, pelvic ligament relaxation, vitamin D deficiency, decreased maternal calcium intake, heparin use, and $\operatorname{PrO}(3,9,14-17)$. The only risk factor in our patient was PrO.

\section{Diagnosis}

SSF diagnosis can be confirmed by radiological imaging. Plain radiography and computed tomography $(\mathrm{CT})$ are not preferred in pregnant women due to radiation effects. Plain radiographs and CT have low sensitivity in SSF diagnosis between 20\%-30\% and $60 \%-75 \%$, respectively (11). Therefore, MRI is the first choice for diagnosis. MRI can detect SSF with approximately 100\% sensitivity $(11,12)$. MRI can be safely used during peripartum period, and SSF has the appearance of a vertical or oblique fracture line in the sacrum and edema in the surrounding bone, as described in our case and in other reported cases $(1,4)$.

\section{Treatment and Prognosis}

Treatment options for SSF are limited due to pregnancy. Treatment is conservative, and pain control is the first priority $(4,14)$. Rest, activity modification and analgesics are generally recommended (4). Oral paracetamol is the most common analgesic that can be safely used in all pregnancy trimesters. Intravenous paracetamol and morphine may be rarely administered in some cases (1). Bed rest is recommended during the early period until adequate pain control is achieved. In patients with decreasing pain, early mobilization (partial loading, gradual ambulation with walking aids) may be initiated to accelerate bone healing and reduce the complications of immobilization $(1,6,14)$. Moreover, osteoporosis treatment should be included in the treatment of patients with PrO (15). SSF is mostly stable, none of the peripartum SSF cases required surgical treatment $(1,14)$. With conservative treatment, these patients returned to their daily living activities in approximately 6 weeks $(1,4)$. Complete recovery of the fracture line was observed on MRI after 4-9 months $(4,14)$. Our patient regained her daily living activities with 12 weeks of conservative treatment before birth.

\section{PrO and Bone Mineral Density}

Four types of PrO have been identified: idiopathic osteoporosis of pregnancy, transient osteoporosis of the hip, post-pregnancy vertebral osteoporosis, and lactation-related osteoporosis (18). Because PrO is a risk factor for SSF, postnatal BMD measurement is recommended for these patients $(1,4,13)$. BMD decreases by an average of $3.5 \%$ during pregnancy; BMD measurement results may vary (15). BMD may be normal, osteopenic, or osteoporotic due to the time between fracture formation and measurement (13). BMD returns to normal in most PrO patients within 5-10 years after birth. Persistent osteoporosis can be described if BMD does not return to normal within this period (19).

Most of the postpartum SSF patients whose BMD was measured did not have PrO, and only one of the three prepartum cases had PrO. Femoral BMD measurements were low in these patients with $\mathrm{PrO}(3,5,8)$. Our patient had PrO (idiopathic type) with low femoral BMD values.

PrO treatment can be continued with calcium and vitamin D replacement because bisphosphonates and calcitonin are not recommended during pregnancy and lactation (15). Furthermore, early mobilization and walking are beneficial for osteoporosis (15).

\section{Type of Birth}

According to literature review, the type of birth was not reported in the first case (8); the second case had NVD at term, despite being recommended with cesarean section (1); and cesarean section was performed in the third case (4). Ozturk et al. (5), presented intrapartum SSF developed in NVD. Although pain starts during pregnancy, NVD is frequently reported in patients with postpartum SSF $(3,9,14)$. Giannoulis et al. (4) recommended cesarean section due to the increased risk of displacement of the sacral fracture, which is associated with the increased tension in the pelvis during NVD. In another patient with PrO who had transient osteoporosis of the hip, femoral fracture was reported during NVD (20). Our patient preferred cesarean section in line with our recommendation.

\section{Conclusion}

SSFs must be considered in the differential diagnosis of lumbar pain, hip pain, and antalgic gait during pregnancy. Considering that these fractures may occur during the prepartum period, early diagnosis using MRI will increase the success of pain control. Moreover, PrO should be considered as a risk factor for SSFs. In pregnant women with SSFs, cesarean section may be recommended as the type of birth considering the possible displacement risk of fracture. 


\section{Acknowledgments}

We would like to thank the patient in the report. We thank Enago - https://www.enago.com.tr/ceviri/ for their assistance in manuscript translation and editing.

\section{Ethics}

Informed Consent: Written informed consent was obtained from the patient.

Peer-review: Externally and internally peer-reviewed.

\section{Authorship Contributions}

Surgical and Medical Practices: H.S., A.A., Concept: H.S., Design: H.S., Data Collection or Processing: H.S., A.A., Analysis or Interpretation: H.S., A.A., Literature Search: H.S., Writing: H.S., A.A.

Conflict of Interest: No conflict of interest was declared by the authors.

Financial Disclosure: The authors declared that this study received no financial support.

\section{References}

1. Pishnamaz M, Sellei R, Pfeifer R, Lichte P, Pape HC, Kobbe P. Low back pain during pregnancy caused by a sacral stres fracture: a case report. J Med Case Rep 2012;6:98.

2. Schmid L, Pfirrmann C, Hess T, Schlumpf U. Bilateral fracture of the sacrum associated with pregnancy: a case report. Osteoporos Int 1999;10:91-3.

3. Hilal N, Nassar AH. Postpartum sacral stress fracture: a case Report. BMC Pregnancy Childbirth 2016;16:96.

4. Giannoulis DK, Koulouvaris P, Zilakou E, Papadopoulos DB, Lykissas MG, Mavrodontidis AN. Atraumatic sacral fracture in late pregnancy: a case report. Global Spine J 2015;5:248-51.

5. Ozturk G, Kulcu DG, Aydog E. Intrapartum sacral stress fracture due to pregnancy-related osteoporosis: a case report. Arch Osteoporos 2013;8:139.
6. Karatas M, Basaran C, Ozgul E, Tarhan C, Agildere AM. Postpartum sacral stress fracture-an unusual case of low-back and buttock pain. Am J Phys Med Rehabil 2008;87:418-22.

7. Goeb V, Strotz V, Verdet M, Le Loet X, Vittecog O. Postpartum sacral fracture associated with heparin treatment. Clin Rheumatol 2008;27:51-3.

8. Grimaud A, Oddo F, Thibaud I, Brocq O, Euller-Ziegler L. [Fracture of the sacrum caused by bone insufficiency in a pregnant woman]. J Radiol 1997;78:511-2.

9. Ha J, Patel NK, White J, Sarraf KM, Radford W. Sacral insufficiency fractures: an underdiagnosed injury during childbirth?: A case report and review of literature. Arch Osteoporos 2015;10:207.

10. The International Society for Clinical Densitometry. 2015 ISCD official positions-adult. 2015. Can be accessed at: http://www. iscd.org/officialpositions/ 2015-iscd-official-positions-adult/. Accessed 25 Apr 2016

11. Tamaki $Y$, Nagamachi A, Inoue $K$, Takeuchi $M$, Sugiura $K$, Omichi $Y$, et al. Incidence and clinical features of sacral insufficiency fracture in the emergency department. Am J Emerg Med 2017;35:1314-6.

12. Lyders EM, Whitlow CT, Baker MD, Morris PP. Imaging and treatment of sacral insufficiency fractures. AJNR Am J Neuroradiol 2010:31:201-10.

13. Rousiere M, Kahan A, Job-Deslandre C. Postpartal sacral fracture without osteoporosis. Joint Bone Spine 2001;68:71-3.

14. Doruk P, Leblebici B, Adam M, Pourbagher A. Sacral insufficiency fracture during pregnancy with a case report. Turk J Phys Med Rehab 2013;59:85-7

15. Tsiridis E, Upadhyay N, Giannoudis PV. Sacral insufficiency fractures: current concepts of management. Osteoporos Int 2006;17:171625.

16. McFarland EG, Giangarra C. Sacral stres fractures in athletes. Clin Orthop Relat Res 1996;329:240-3.

17. Thienpont E, Simon JP, Fabry G. Sacral stress fracture during pregnancy-a case report. Acta Orthop Scand 1999;70:525-6.

18. Kohlmeier L, Marcus R. Calcium disorders of pregnancy. Endocrinol Metab Clin North Am 1995;24:15-39.

19. Nordin BE, Roper A. Post-pregnancy osteoporosis; a syndrome? Lancet 1955:268:431-4.

20. Thomas E, Cox C, Murphy D, Beddard K. Hip fracture during labour due to transient osteoporosis of the hip in pregnancy. J Obstet Gynecol 2000;20:197-8. 